\title{
OPTIMALISASI PELAKSANAAN BIMBINGAN KONSELING OLEH GURU KELAS BAGI PESERTA DIDIK SEKOLAH DASAR DI KOTA BOGOR
}

\author{
Yuli Mulyawati ${ }^{1}$, Nur Hikmah², Ade Wijaya ${ }^{3}$ \\ ${ }^{123}$ PGSD FKIP Universitas Pakuan \\ 1yuli_mulyawati@unpak.ac.id, 2nur.hikmah@unpak.ac.id, \\ 3ade.wijaya@unpak.ac.id
}

\begin{abstract}
This study aims to see the optimization of counseling guidance by classroom teachers in elementary schools in the city of Bogor as the executor of counseling guidance that seeks to overcome the problems experienced by students in learning. The research method used in this study is a qualitative research method, which is naturalistic research because in carrying out the research it is carried out in natural conditions following the reality in the field. This research was carried out at SDN Bantar Jati 9 Kota Bogor in grade 3, totaling 25 people, the class teacher was Mrs. Ely Rahmawati. The results of the research based on the results of the questionnaire are that it can be seen that there is an even assessment in the teacher's statement guiding so that students can accept every weakness they have, from these results provide a different rater for each child. In the results of the interview with the 3rdgrade teacher at SDN Bantar Jati 9 Kota Bogor, several things were conveyed regarding the counseling guidance carried out by him, including guiding, reminding, giving advice, giving punishment, correcting, providing motivation, and giving examples. Optimization of the implementation of counseling guidance by classroom teachers can be carried out including by guiding students to pray before learning and after carrying out learning activities, Teachers guide students to become independent children, Teachers tell students about how to behave politely, politely to teachers and peers, teachers guide students to be responsible when they make mistakes, teachers guide students to have empathy for others, teachers give explanations about how to learn well and effectively, teachers guide students to calm down in preparing themselves facing the test, the teacher motivates students to continue to be enthusiastic in learning. Based on this, the implementation of counseling guidance by classroom teachers in elementary schools in the city of Bogor can be concluded to be carried out optimally.
\end{abstract}

Keywords: Counseling Guidance, Class Teacher. Learners

\section{ABSTRAK}

Penelitian ini mempunyai tujuan untuk melihat optimalisasi bimbingan konseling oleh guru kelas di sekolah dasar di Kota Bogor sebagai pelaksana bimbingan konseling yang berupaya mengatasi masalah yang yang dialami oleh peserta didik dalam pembelajaran. Metode penelitian yang diguanakan dalam penelitian ini 
adalah metode penelitian kualitatif, yaitu merupakan penelitian yang bersifat naturalistik karena dalam melaksanakan penelitiannya dilakukan pada kondisi yang alamiah sesuai dengan kenyataan yang ada dilapangan. Penelitian ini dilaksanakan di SDN Bantar Jati 9 Kota Bogor di kelas 3 yang berjumlah 25 orang, guru kelasnya bernama ibu Ely Rahmawati. Hasil penelitian berdasarkan hasil angket adalah dapat terlihat bahwa penilaian yang merata ada pada pernyataan guru membimbing agar peserta didik dapat menerima setiap kelemahan yang dimilikinya, dari hasil tersebut memberikan penilai yang berbeda setiap anaknya. Hasil wawancara dengan guru kelas 3 SDN Bantar Jati 9 Kota Bogor ada beberapa hal yang di sampaikan berkaitan bimbingan konseling yang dilakukan oleh beliau antara lain : membimbing ,mengingatkan, memberikan nasehat, memberikan hukuman , korektor, memberikan motivasi dan memberikan contoh. Optimalisasi pelaksanaan bimbingan konseling oleh guru kelas dapat terlaksana di antaranya dengan membimbing peserta didik untuk berdoa sebelum pembelajaran dan sesudah melakukan kegiatan pembelajaran, Guru membimbing peserta didik untuk menjadi anak yang mandiri, Guru memberitahu peserta didik mengenai caranya bertingkah laku yang santun, sopan kepada guru dan teman sebaya, Guru melakukan pembimbingan pada peserta didik untuk dapat bertanggung jawab saat berbuat kesalahan, Guru membimbing peserta didik agar memiliki rasa empati pada orang lain, Guru memberikan penjelasan mengenai caranya untuk belajar yang baik dan efektif, Guru membimbing peserta didik untuk tenang dalam mempersiapkan diri menghadapi ulangan, Guru memberikan motivasi kepada peserta didik untuk terus bersemangat dalam belajar. Berdasarkan hal tersebut pelaksanaan bimbingan konseling oleh guru kelas di sekolah dasar di kota bogor dapat disimpulkan dilaksanakan secara optimal.

Kata Kunci : Bimbingan Konseling, Guru Kelas. Peserta Didik. Pendahuluan

\section{A. Pendahuluan}

Bimbingan Konseling adalah
upaya yang dilaksanakan oleh
seorang guru dalam memberikan
bantuan kepada peserta didik yang
mengalami permasalahan dalam
pelaksanaan pembelajaran sehingga
dihasilkan sebuah solusi yang
dihasilkan untuk mengatasi
permasalahan tersebut. Banyak factor yang dapat menjadikan permasalahan dalam pelaksanaan pembelajaran antara lain: kebanyakan peserta didik kerap mengalami seperti munculnya rasa malas untuk belajar, karena lebih suka bermain, kurangnya motivasi dari keluarga dan lingkungan untuk belajar, emosi yang terkadang turun naik sehingga sering kali terjadi ketdakstabilan dalam perilaku. Terkadang peserta didik yang mengikuti proses pembelajaran di kelas menghadapi masalah yang berasal dari dirinya sendiri dan 
lingkungan sekitar yang kurang merespon positif dalam pembelajaran.

Dari permasalahan peserta didik yang kerap ditemui di lapangan, kita dapat amati ada beberapa peserta didik yang bermain sendiri sewaktu guru sedang menjelaskan pelajaran, ada juga yang malas dan tidak mau mengerjakan pekerjaan rumah.

Dari permasalahan tersebut yang dialami peserta didik guru melakukan berbagai uapaya dalam mengatasi masalah yang dihadapi oleh peserta didik. Hal yang perlu dilaksankan oleh guru dalam upaya menangani masalah yaitu dengan melaksanakan bimbingan dan konseling secara khusus kepada peserta didik._Guru dalam pelaksanaan pembelajaran akan selalu menerapkan keterampilan memberi penguatan agar peserta didik dapat termotivasi saat kegiatan pembelajaran sedang berlangsung (Firdaus et al., 2020)

Guru kelas adalah menjadi sebuah idola bagi peserta didik. Keberadaannya sebagai jantung dalam pendidikan tidak bisa di abaikan. Baik atau tidaknya pendidikan tergantungnya kepada guru. Adapun peran guru tidak hanya sebagai pendidik, akan tetapi ada peran lainnya juga diantaranya pengajar, pembimbing belajar, penasihat jika ada masalah, pembaru dalam pembelajaran, model yang dapat ditiru, dan teladan yang patut diteladani, pribadi yang memesona, peneliti dalam pembelajaran, pendorong kreativitas dan pembangkit pandangan dalam pembaharu pembelajaran. Guru dan peserta didik adalah dua orang manusia yang tidak dapat di pisahkan dari sebuah kaitan dalam pendidikan. Dimana guru di sanalah akan ada peserta didik yang ingin belajar dari guru. Sebaliknya, di mana ada peserta didik di situ ada guru yang ingin memberikan arahan dan bimbingan kepada anak didiknya.

Peran guru dalam pembelajaran adalah paling dominan meskipun saat ini diharapkan peserta didik yang lebih aktip, akan tetapi pada kenyataan tetap guru sebagai fasilitator dalam pembelajaran sehingga dibutuhkan komunikasi efektif antara guru dan peserta didik terutama dalam pembelajaran. Pada penelitian ini, peran orang tua di masa pandemic covid 19 ini juga memiliki andil yang sangat penting karena proses kegiatan belajar mengajar banyak terjadi di rumah. Menurut (Hero, H.,Sni, 2018), karena peran orang tua dalam kegiatan pembelajaran akan 
mampu meningkatkan motivasi anak dalam belajar.(Disjayanti Fauzi \& Budi Sartika, 2020)

Dalam pengertian yang sederhana peran guru terutama wali kelas merupakan orang yang memberikan ilmu pengetahuan kepada peserta didiknya. (Djamarah, 2010)

Dilihat dari peran guru terutama wali kelas sebagai guru bimbingan konseling yang berperan untuk membimbing peserta didik dan juga melakukan pendekatan dalam menghadapi peserta didik yang mempunyai sifat yang beraneka ragam, maka guru wali kelas sekaligus sebagai guru bimbingan dan konseling harus memiliki sifat ramah dimana nantinya dengan sifat tersebut guru dapat merangkum semua peserta didiknya.

Menurut (Arifin, 2013) dalam penelitiannya menyatakan bahwa upaya yang dilakukan guru dalam membimbing dan memberikan semangat pada peserta didik khususnya bagi peserta didik di Sekolah Dasar /madrasah ibtidaiyah yang masih dalam taraf pertumbuhan dan perkembangan dengan melaksanakan bimbingan belajar, diantaranya adalah dengan mengadakan pengayaan dan perbaikan yaitu bentuk pengajaran yang bersifat membantu untuk menyembuhkan atau membetulkan pembelajaran yang membuat pembelajaran menjadi lebih baik.

Berdasarkan hasil wawancara dengan guru permasalahan yang terjadi dan seringkali menjadi dominan adalah motivasi belajar yang kurang, dalam proses pembelajaran sering sekali peserta didik hanya bermain dan mengobrol tentang permainan yang mereka mainkan di gawai, mereka lebih senang mengobrol dibandingakan mengerjakan berbagai pekerjaan yang diberikan oleh guru. Dalam uapaya mencapai tujuan pembelajaran yang baik sering kali guru harus melakukan upaya-upaya bimbingan konseling terutama dilakukan kepada peserta didik dominan mengalami permasalahan pembelajaran. bimbingan konseling di sekolah dasar biasanya dilakukanoleh guru kelas karena di sekolah tersebut tidak terdapat guru yang khusus dalam bimbingan konseling, beberapa pelayanan bimbingan dan konseling dilaksanakan oleh guru wali kelas untuk mengatasi permasalahan yang ditimbulkan. Pelayanan yang dilaksanakan oleh guru wali kelas baik 
pada saat pembelajaran itu dilakasanakan atau setelah pembelajaran telah selesai. Hal ini sejalan dengan hasil penelitian (Khabibah, 2017) Bentuk-bentuk bimbingan dan konseling yang dapat dilakukan oleh guru wali kelas dalam melaksanakan Bimbingan Konseling diantaranya: a.) bimbingan secara pribadi, bimbingan hal sosial, bimbingan dalam belajar, dan bimbingan dalam jenjang karier yang akan datang. b). melaksanakan kegiatan pendukung lainnya dianataranya kegiatan himpunan pada masalah yang timbul, Alih tangan kasus bagi yang mempunyai masalah yang menimbulkan kasus, dan melaksanakan kunjungan rumah untuk lebih memperdalam dan mengetahui permasalahan yang dihadapi serta penanganannya yang terbaik buat peserta didik.

Menurut jurnal peneltitian yang dilakukan oleh (Goodman-Scott et al., 2016) dengan judul School Counseling Faculty Perceptions and Experiences Preparing Elementary School Counselor. Berdasarkan hasil penelitiannya menunjukan bahwa pelaksanan bimbingan dan konseling yang dilakukan di sekolah dasar sangatlah penting untuk dilaksanakan.
Bimbingan dan konseling di sekolah dasar akan memberikan fondasi yang sangat penting bagi kehidupan peserta didik di masa yang akan datang.

\section{B. Metode Penelitian}

Metode yang digunakan dalam penelitian ini adalah jenis penelitian kualitatif. Penelitian kualitatif merupakan penelitian yang bersifat naturalistik atau berdasarkan hal nyata di lapangan sesuai apa adanya karena penelitiannya dilakukan pada kondisi yang alamiah. Dimana dalam pengolahan data seorang peneliti juga menggunakan data kualitatif. Analisis data kualitatif adalah proses dalam mencari serta menyusun hasil penelitian secara sistematis, data yang diperoleh secara observasi dan data hasil wawancara disajikan secara natural sehingga mudah dipahami dan dapat diinformasikan kepada orang lain yang membacanya.

Pengertian penelitian kualitatif menurut (Creswell, 2012) merupakan penelitian interpretif, artinya peneliti terlibat dalam pengalaman yang berkelanjutan dan terus menerus dengan para partisipan dalam hal ini adalah peserta didik. Tempat penelitan adalah SDN Bantar Jati 9 
Kota Bogor di kelas 3 yang berjumlah

25 orang, guru kelasnya bernama ibu

Ely Rahmawati. Penelitian di laksanakan dari bulan Mei-November 2021. Dilakukan secara daring dan luring.

\section{Hasil Penelitian dan}

\section{Pembahasan}

Berdasarkan hasil angket yang diberikan kepada peserta didik berkaitan dengan otimalisasi peran guru sebagai pelaksana bimbingan konseling diperoleh hasil sebagai berikut : 
Tabel 3.1 Hasil Angket Peserta Didik

\begin{tabular}{|c|c|c|c|c|c|c|c|}
\hline \multirow[t]{2}{*}{ No } & \multirow[t]{2}{*}{ Pernyataan } & \multicolumn{3}{|c|}{$\begin{array}{l}\text { Jawaban peserta } \\
\text { didik }\end{array}$} & \multicolumn{3}{|c|}{ Persentase } \\
\hline & & $\mathrm{Ya}$ & KD & TP & $\mathrm{Ya}$ & KD & TP \\
\hline 1 & $\begin{array}{l}\text { Guru membimbing peserta didik untuk } \\
\text { berdoa sebelum dan sesudah melakukan } \\
\text { kegiatan }\end{array}$ & 25 & & & $100 \%$ & & \\
\hline 2 & $\begin{array}{l}\text { Guru memberikan penjelasan tentang } \\
\text { bagaimana cara memahami kelebihan dan } \\
\text { kekurangan yang dimiliki peserta didik }\end{array}$ & 13 & 12 & & $52 \%$ & $48 \%$ & \\
\hline 3 & $\begin{array}{l}\text { Guru mengikut sertakan peserta didik yang } \\
\text { memiliki bakat pada setiap perlombaan }\end{array}$ & 19 & 6 & & $76 \%$ & $24 \%$ & \\
\hline 4 & $\begin{array}{l}\text { Guru membimbing agar peserta didik dapat } \\
\text { menerima setiap kelemahan yang dimilikinya }\end{array}$ & 12 & 3 & 10 & $48 \%$ & $12 \%$ & 40 \\
\hline 5 & $\begin{array}{l}\text { Guru membimbing untuk mengatasi } \\
\text { kelemahan yang miliki peserta didik }\end{array}$ & 18 & 7 & & $72 \%$ & $28 \%$ & \\
\hline 6 & $\begin{array}{l}\text { Guru membimbing agar peserta didik } \\
\text { berpikir positif }\end{array}$ & 23 & 2 & & $92 \%$ & $8 \%$ & \\
\hline 7 & $\begin{array}{l}\text { Guru memotivasi peserta didik untuk } \\
\text { meningkatkan rasa percaya diri }\end{array}$ & 24 & & 1 & $96 \%$ & & $4 \%$ \\
\hline 8 & $\begin{array}{l}\text { Guru membimbing peserta didik untuk } \\
\text { menjadi anak yang mandiri }\end{array}$ & 25 & & & $100 \%$ & & \\
\hline 9 & $\begin{array}{l}\text { Guru memberitahu peserta didik tentang } \\
\text { cara bertingkah laku yang sopan kepada } \\
\text { guru dan teman sebaya }\end{array}$ & 25 & & & $100 \%$ & & \\
\hline 10 & $\begin{array}{l}\text { Guru membimbing peserta didik untuk } \\
\text { menjaga perasaan teman dikelas maupun } \\
\text { diluar sekolah }\end{array}$ & 19 & 4 & 2 & $76 \%$ & $16 \%$ & $8 \%$ \\
\hline 11 & $\begin{array}{l}\text { Guru membimbing peserta didik untuk } \\
\text { mengembangkan kemampuan } \\
\text { berkomunikasi secara tertulis melalui hasil } \\
\text { karya berupa kalimat pendek atau cerita }\end{array}$ & 18 & 7 & & $72 \%$ & $28 \%$ & \\
\hline 12 & $\begin{array}{l}\text { Guru membimbing peserta didik untuk } \\
\text { bertanggung jawab saat anda berbuat } \\
\text { kesalahan }\end{array}$ & 25 & & & $100 \%$ & & \\
\hline 13 & $\begin{array}{l}\text { Guru membimbing peserta didik untuk } \\
\text { memiliki rasa empati pada orang lain }\end{array}$ & 25 & & & $100 \%$ & & \\
\hline 14 & $\begin{array}{l}\text { Guru memberikan penjelasan mengenai cara } \\
\text { belajar yang baik }\end{array}$ & 25 & & & $100 \%$ & & \\
\hline 15 & $\begin{array}{l}\text { Guru membimbing peserta didik yang } \\
\text { mengalami kesulitan dalam belajar }\end{array}$ & 24 & 1 & & $96 \%$ & $4 \%$ & \\
\hline
\end{tabular}




\begin{tabular}{|c|c|c|c|c|c|c|}
\hline 16 & $\begin{array}{l}\text { Guru membimbing peserta didik untuk } \\
\text { tenang dalam mempersiapkan diri } \\
\text { menghadapi ulangan }\end{array}$ & 25 & & & $100 \%$ & \\
\hline 17 & $\begin{array}{l}\text { Guru memotivasi peserta didik untuk } \\
\text { semangat dalam belajar }\end{array}$ & 25 & & & $100 \%$ & \\
\hline 18 & $\begin{array}{l}\text { Guru membimbing peserta didik untuk } \\
\text { menentukan cita-citanya }\end{array}$ & 18 & 1 & 6 & $72 \%$ & $4 \%$ \\
\hline 19 & $\begin{array}{l}\text { Guru membimbing peserta didik yang } \\
\text { mengalami masalah dalam menentukan cita- } \\
\text { cita }\end{array}$ & 17 & 4 & 4 & $68 \%$ & $16 \%$ \\
\hline 20 & $\begin{array}{l}\text { Guru membimbing peserta didik untuk } \\
\text { mempersiapkan diri masuk ke tingkat SMP }\end{array}$ & 24 & 1 & & $96 \%$ & $4 \%$ \\
\hline
\end{tabular}

Berdasarkan Hasil angket dapat terlihat bahwa penilaian yang merata ada pada pernyataan Guru membimbing agar peserta didik dapat menerima setiap kelemahan yang dimilikinya, dari hasil tersebut memberikan penilai yang berbeda setiap anaknya, hal ini di karenakan tidak semua anak memiliki permasalahan yang berkaitan dengan kurangnya kepercayaan diri anak karena anak mempunyai kelemahan. Sedangkan pernyataan Guru membimbing peserta didik untuk berdoa sebelum pembelajaran dan sesudah melakukan kegiatan pembelajaran, Guru membimbing peserta didik untuk menjadi anak yang mandiri, Guru memberitahu peserta didik mengenai bagaimana cara bertingkah laku yang sopan, santun dan ramah kepada guru dan teman sebaya, Guru selalu membimbingpeserta didik untuk bertanggung jawab saat peserta didik berbuat kesalahan, Guru membimbing peserta didik untuk memiliki rasa empati pada orang lain, Guru memberikan penjelasan tentang cara belajar yang tepat dan baik, Guru membimbing peserta didik untuk tenang dalam mempersiapkan diri menghadapi ulangan, Guru selalu memberikan motivasi kepada peserta didik untuk selalu semangat dalam belajar hal ini dapat di lihat dari jawaban peserta didik yang sama jawabanya yaitu $100 \%$ menjawab ya setelah di konfirmasi kepada peserta didik melalui wawancara mereka menyebutkan dalam setiap kesempatan pembelajaran, guru selalu memberikan bimbingan dan arahan seperti itu terus menerus. Dapat dilihat pada gambar berikut ini. 


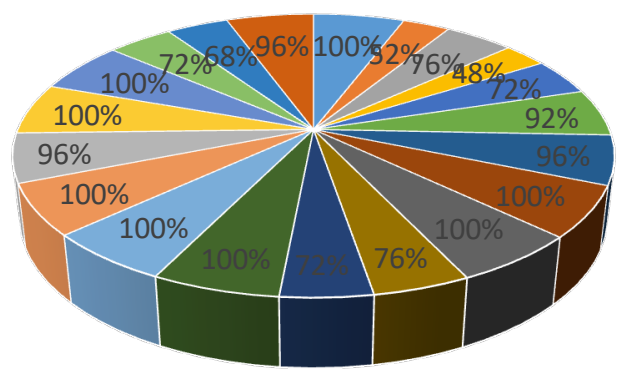

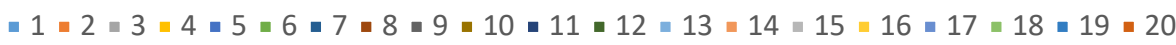

Gambar 3.1 Persentase Jawaban Angket peserta didik

Hasil wawancara dengan guru wali kelas 3 SDN Bantar Jati 9 Kota Bogor ada beberapa hal yang di sampaikan berkaitan bimbingan konseling yang dilakukan oleh beliau antara lain :

Berdasarkan hasil wawancara dengan guru kelas 3 SDN Bnatar Jati 9 ada beberapa hal yang di sampaikan berkaitan bimbingan konseling yang dilakukan oleh beliau antara lain :

1. Membimbing

Guru memberikan bimbingan belajar secara kelompok maupun individual. Bimbingan individual diberikan kepada peserta didik yang yang kurang dalam hasil belajarnya serta prestasinya menurun. Bimbingan yang diberikan dilaksanakan pada saat jam pelajaran telah berakhir.

2. Mengingatkan

Guru selalu meberikan arahan dan mengingatkan kepada siswa untuk bertatakrama yang sopan, santun dan beretika kepada peserta didik. Tingkah laku yang sopan, santun dan beretika dilakukan kepada siapa saja baik kepada orang tua, guru, teman sebaya ataupun kepada orang lain. Hal ini dilakukan dalam rangkah menumbuhkan sikap dan perilaku yang baik.

3. Memberikan nasehat

Guru memberikan nasehat kepada peserta didik untuk selalu mentaatti segala peraturan yang ada baik di rumah, di sekolah maupun di lingkungan masyarakat setempat, hal ini dalam rangka menumbuhkan sikap displin, kepatuhan dan tanggung jawab kepada peserta didik.

4. Memberikan Hukuman

Guru memberikan ganjaran atau hukuman kepada peserta didik yang tidak mentaati aturan yang 
ada terutama aturan yang ada di sekolah dan tidak melaksanakan sikap yang baik.

5. Korektor

Guru selalu memberikan umapan balik kepada peserta didik setiap kali peserta didik melaksanakan kewajibannya. Guru juga memberikan arahan dan masukan terhadap sikap peserta sebagai bentuk korektor agar peserta didik lebih baik di masa yang akan datang.

6. Memberikan Motivasi

Sangat penting seorang guru dapat memberikan motivasi kepada peserta didik agar peserta didik bersemangat dalam melaksanakan pembelajaranya baik di sekolah maupun di rumah.

7. Memberikan Contoh

Guru merupakan teladan bagi peserta didik oleh karena itu guru harus memberikan contoh yang baik bagi peserta didik dalam bertutur kata, bersikap, dan bertingkah laku yang dapat di tiru dan di teladani oleh peserta didik hal yang dilakukan oleh guru diantaranya menggunakan seragam yang sesuai dengan aturan, berangkat tepat waktu, dan melaksanakan tugas sebagai seorang guru serta melaksanakan tugas piket. Guru kelas Imemberikan contoh pada peserta didik dengan selalu bertanggung jawab pada perbuatan yang dilakukan.

Berdasarkan data tersebut bila kita lihat sejalan dengan pendapat (Mulyati \& Kamaruddin, 2020) peran guru BK adalah sebagai informatory atau pemberi informasi, organisator yang merancang dan melaksanakan oraganisasi kelas, motivator dalm pembelajaran, director atau pengarah dalam pembelajaran, inisiator atau pemberi inisiatif, transmitter, fasilitator atau yang memfasilitasi, mediator, dan evaluator atau yang memberikan umpan balik dan tindak lanjut dalam pembelajaran.

Sedangkan

dalam

melaksanakan bimbingan dan konseling ini diperlukan sebuah metode yang dapat dilaksanakan secara efektif dan efesiian yaitu dengan cara melaksanakan bimbingan terhadap peserta didik secara kelompok dan juga secara individual. Konseling dapat dilakukan secara individual apabila dalam pelaksanaan pembelajaran timbul masalah secara pribadi kepada peserta didik. Konseling biasanya 
lebih mendalam dan memberikan solusi dalam penyelesaian masalah.

Menurut (Rahman, 2017) Metode dalam melaksanakan bimbingan kepada peserta didik dalam pelaksanaan bimbingan belajar dilakukan dengan metode bimbingan secara individual dan metode bimbingan secara berkelompok. Dalam melaksanakan bimbingan secara berkelompok guru diharapkan memiliki keterampilan dalam mengelola peserta didik selama pembelajaran. Guru kelas diharapkan mempunyai kemampuan memusatkan perhatian peserta didik terhadap materi yang akan disampaikan guru dalam kelas, untuk itu guru kelas dituntut cepat dan tepat dalam membuat dan memberi keputusan untuk peserta didik.

Guru kelas diharapkan dalam pelaksanaan bimbingan dan konseling mampu meningkatkan potensi yang ada dalam diri peserta didik, motivasi dan prestasi peserta didik. Pelayanan yang dapat diberikan dalam rangka bimbingan dan konseling perlu diselenggarakan pada tingkat pendidikan dasar dimana diharapkan pribadi dan segenap potensi yang ada dalam diri peserta didik dapat berkembang secara optimal sesuai dengan

tahapan-tahapan

perkembangan.

Bimbingan dan konseling pada tingkat pendidikan dasar dilaksanakan oleh guru wali kelas, dimana pelayanan bimbingan dan konseling dilaksanakan di sekolah dasar sepenuhnya oleh guru wali kelas. Oleh karena itu peranan guru wali kelas sebagai pelaksana penting dalam kegiatan bimbingan dan

konseling, harus memiliki kemampuan dan keahlian dalam merancang, melaksanakan, mengevaluasi, serta menindaklanjuti semua kegiatan bimbingan dan konseling yang disesuaikan dengan tingkat kebutuhan peserta didik. (Mulyadi, 2019).

\section{Berdasarkan}

penelitian (Rahman, 2017) bahwa materi yang diberikan dalam pelayanan bimbingan konseling diantaranya adalah bimbingan belajar yang meliputi peningkatan motivasi belajar peserta didik, pemberian peningkatan motivasi belajar, peningkatan keterampilan belajar dan pengembangan sikap belajar dan kebiasaan belajar yang dapat meningkatkan hasil belajar peserta didik. Metode pembimbingan peserta didik dalam pelaksanaan bimbingan belajar dapat dilaksanakan 
melalui metode bimbingan secara individual dan metode bimbingan secara berkelompok.

\section{Kesimpulan}

Optimalisasi pelaksanaan bimbingan konseling oleh guru kelas dapat terlaksana di antaranya dengan membimbing peserta didik untuk berdoa sebelum pembelajaran dan sesudah melakukan kegiatan pembelajaran, Guru membimbing peserta didik untuk menjadi anak yang mandiri, Guru memberitahu peserta didik mengenai caranya bertingkah laku yang santun, sopan kepada guru dan teman sebaya, Guru melakukan pembimbingan pada peserta didik untuk dapat bertanggung jawab saat berbuat kesalahan, Guru membimbing peserta didik agar memiliki rasa empati pada orang lain, Guru memberikan penjelasan mengenai caranya untuk belajar yang baik dan efektif, Guru membimbing peserta didik untuk tenang dalam mempersiapkan diri menghadapi ulangan, Guru memberikan motivasi kepada peserta didik untuk terus bersemangat dalam belajar mendapatkan jawaban 100\% dari peserta didik hal ini terliahat dengan jawaban peserta didik dengan menjawab ya, kemudian hasil jawaban peserta didik di konfirmasi angket di konfirmasi melalui wawancara dimana peserta didik menyebutkan dalam setiap kesempatan pembelajaran, guru selalu memberikan bimbingan dan arahan secara terus menerus serta melakukan konseling bagi peserta didik yang mempunyai masalah-masalah yang berkaitan dengan pembelajaran

Berdasarkan hal tersebut diatas pelaksanaan bimbingan konseling oleh guru kelas di sekolah dasar di kota bogor dapat disimpulkan dilaksanakan secara optimal.

\section{DAFTAR PUSTAKA}

Creswell, J. W. (2012). Educational Research "Planning, Conducting, and Evaluating Quantitative and Qualitative Research". Pearson.

Djamarah, S. B. (2010). Guru \& Anak Didik dalam Interaksi Edukatif Suatu Pendekatan Teoritis Psikologis. Rineka Cipta.

Kemendikbud, D. G. dan T. K. (2016). Panduan Operasional Penyelenggaraan Bimbingan dan Konseling Sekolah Dasar. In Academia. Edu (Issue 1).

Arifin, L. (2013). Upaya Konselor Dalam Membimbing Belajar Siswa Di Sekolah Dasar / Madrasah Ibtidaiyah. Jurnal Bimbingan Konseling Islam, 4(2), 
201-218. file:///C:/Users/Win

10/Downloads/KTI BARU

SHELA/1004-3591-1-PB.pdf

Creswell, J. W. (2012). Educational Research "Planning, Conducting, and Evaluating Quantitative and Qualitative Research". Pearson.

Disjayanti Fauzi, O., \& Budi Sartika, S. (2020). Profil Peran Guru Sd Dalam Kegiatan Belajar Mengajar Dari Rumah Di Masa Pandemi Covid-19. Pendas: Jurnal IImiah Pendidikan Dasar, V(Vol 5 Nomor 2 Desember 2020). https://doi.org/10.23969/jp.v5i2.3 312

Djamarah, S. B. (2010). Guru \& Anak Didik dalam Interaksi Edukatif Suatu Pendekatan Teoritis Psikologis. Rineka Cipta.

Firdaus, M., Yunus, M., \& Dewi Wahyuni Andari, K. (2020). Deskripsi Pemberian Penguatan Guru Terhadap Motivasi Belajar Pada Siswa Kelas V Di Sdn 011 Tarakan. Pendas: Jurnal IImiah Pendidikan Dasar, V(Vol 5 No 1 June 2020). https://doi.org/10.23969/jp.v5i1.2 583

Goodman-Scott, E., Watkinson, J. S., Martin, I., \& Biles, K. (2016).
School Counseling Faculty Perceptions and Experiences Preparing Elementary School Counselors. The Professional Counselor, 6(4), 303-317. https://doi.org/10.15241/egs.6.4.3 03

Khabibah, Z. A. (2017). Peran Guru Kelas Sebagai Pelaksana Bimbingan Konseling Bagi Peserta Didik Di SD Muhamadiyah 13 Surakarta. Journal of Chemical Information and Modeling, 53(9), 1689-1699.

Mulyadi. (2019). PELAKSANAAN DAN PENGELOLAAN PELAYANAN BIMBINGAN DAN KONSELING DI SD/MI. Jurnal AlTaujih, 5(2).

Mulyati, S., \& Kamaruddin, K. (2020). Peran Guru dalam Pelaksanaan Bimbingan Konseling. Al-Liqo: Jurnal Pendidikan Islam, 5(02), 172-184.

https://doi.org/10.46963/alliqo.v5i 02.241

Rahman, A. (2017). Peranan Guru Bimbingan dan Konseling Terhadap Pelaksanaan Bimbingan Belajar Di SMK Negeri 1 Loksado. Jurnal Mahasiswa Bimbingan Konseling, 2(1), 1-14. 